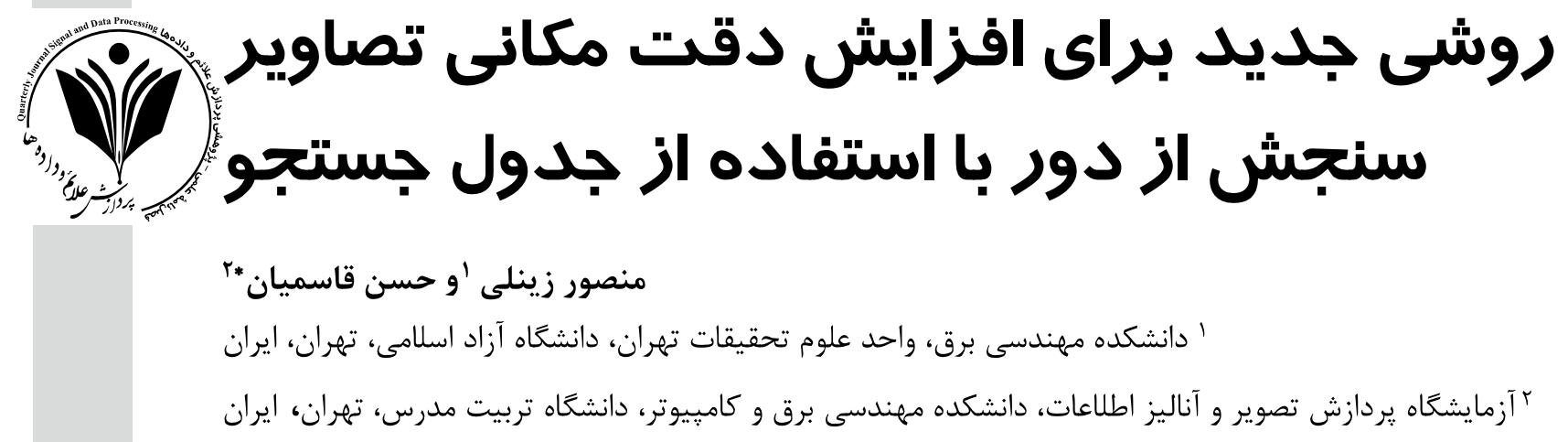

يزوهشهاى مختلفى براى افزايش دقت مكانى تصاوير با هدف تجزيه يِيكسلهاى مخلوط در سنجش از دور انجام شده است. اين روشها و و

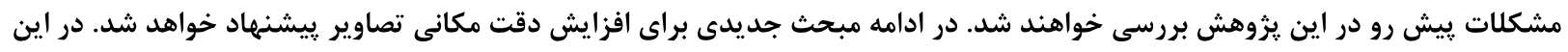

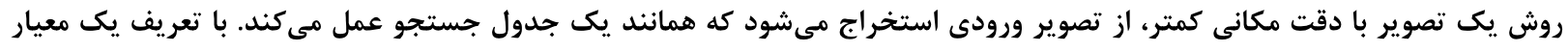

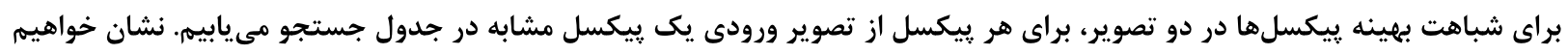

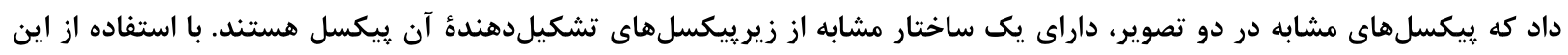

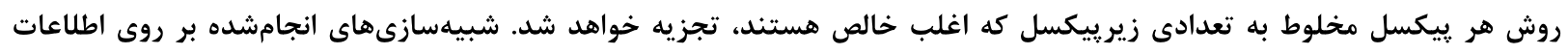

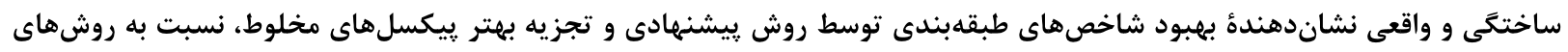
قابل مقايسه است. وازَّان كليدى: افزايش دقت مكانى، زيرِيكسل، جدول جستجو، تجزيه بِيكسلهاى مخلوط

\title{
A Novel Method for Increasing the Spatial Resolution of Remote Sensing Images Using Lookup Table \\ Mansoor Zeinali ${ }^{1}$ \& Hassan Ghassemian ${ }^{* 2}$ \\ ${ }^{1}$ Department of Electrical Engineering, Science and Research Branch, Islamic Azad University, Tehran, Iran. \\ ${ }^{2}$ Image processing and Information Analysis Lab, Faculty of Electrical and Computer Engineering, Tarbiat Modares University, Tehran, Iran.
}

\begin{abstract}
Different methods have been proposed to increase the image spatial resolution by mixed pixels decomposition. These methods can be divided into two groups. Some research have been attempted to obtain percentages of sub pixels and the other try to obtain their locations. These methods and their problems will be examined in this study. Common methods are reviewed with more emphasis. Finally, a new method for increasing the spatial resolution will be proposed to resolve some deficiencies of existing methods. Especially this method, instantly takes percentages and locations of mixed pixels end members without no use of additional information. This method applies a proper lookup table, which is derived from ian input image. By defining a similarity metric function, we obtain a similar pixel for every input pixel. These similar pixels have equal sub pixel structures; hence, an input pixel will be decomposed to a proper set of sub pixels. In the high quality images, these sub pixels usually, belong to pure classes. This proposed method is examined on
\end{abstract}


four sets of artificial and real data. First we degrade these data sets by averaging filtering, and then we restore degraded data, using this method and two other methods. One of these methods is a hard classification and the other is a combination of fuzzy c-means and direct method to obtain percentages and locations of sub pixels respectively. We obtain percent of correction classification and KAPPA criterions for these methods. Simulation results on artificial, real data show a good sub pixels decomposition performance of proposed method relative to those of other comparable methods. By particular, this method shows at least $7 \%$ of improvement in artificial and $2 \%$ in real data relative to other methods.

Keywords: spatial resolution, change the image scale, lookup table, subpixel decomposition

دو روش كلى براى افزايش دقت مكانى تصاوير سنجش از

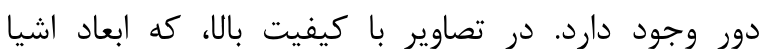

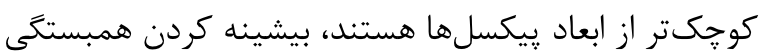
مكانى بين زيرييكسلها مورد نظر است. در تصاوير با كيفيت يايين، يكسان كردن همبستغى مكانى بين زيرييكسل ها با

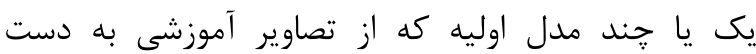
آمدهاند، هدف اصلى است.

در تصاوير با دقت كيفيت بالا، كه در اين يزوهش بررسى مىشوند، يس از تعيين درصد زيرييكسلها، بهطور

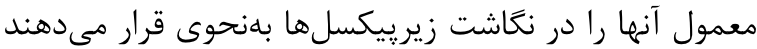
كه همبستكى مكانى تصوير بيشتر شود؛ بنابراين بررسى مسائل زيرييكسلها در اين تصاوير را مىتوان به دو دسته نحوه محاسبه نسبت طبقههاى تشكيل دهنده يك ييكسل و نحوء تعيين محل زيرييكسل ها، تقسيم كرد.

\section{r-1 - روشهاى محاسبةٌ نسبت طبقهها} با توجه به يِيشرفتهاى اخير در زمينه مكانيابى جغرافيايى و كسب اطلاعات سطح زمين، نياز زيادى به مقايسهُ تصاوير با مقياسهاى مختلف و روشهاى ارزانقيمت در اكتساب اطلاعات است. در سالهاى كذشته سعى شده كه بر اساس

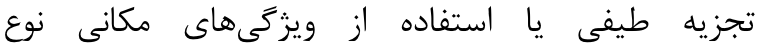
زيرييكسلها و محل آنها در تصاوير با تفكيك كم تخمين

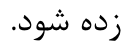

تحليل مخلوط طيفى يكى از روشهاى تحليل زيرييكسل در آشكارسازى العوها است. فرض اصلى در اين

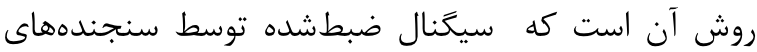
ماهواره براى هر يِيكسل يك تركيب خطى وزن داده شده ز $r_{i j}^{l}=\sum_{k=1}^{K} f_{i j k} c_{k}^{l}+\varepsilon_{i j}^{l}, \quad \sum_{k=1}^{K} f_{i j k}=1$

شدت بازتابشهاى خالص بهسختى از نواحى آموزشى خالص

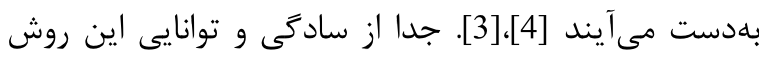
در تخمين دقيق زيرييكسلها در شرايط خاص مشكلاتى در
- 1

مشكل بزرگى كه اغلب تصاوير با كيفيت پايين دارند،

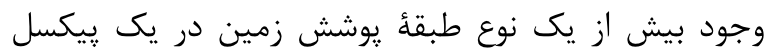

است كه بهنام ييكسل مخلوط شناخته مىشود. اين مشكل زمانى رخ مى دهد كه ابعاد ييكسل از ابعاد طبقههاى موجود در آن (زيرييكسل) بزرگتر بوده يا طبقهها در هم ادغام شده باشند.

ييكسلهاى مخلوط تأثير زيادى در ميزان دقت

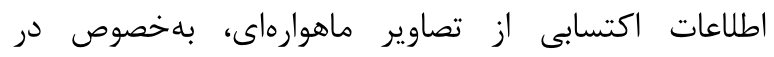

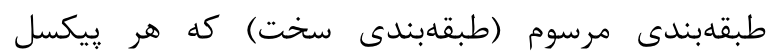
نمايشدهنده يك طبقه است، دارند. درنتيجه براى افزايش هرم دقت طبقهبندى اطلاعات، نياز به افزايش دقت مكانى با هدف كاهش ييكسل هاى مخلوط داريم. در اين مقاله روش جديد افزايش دقت مكانى تصاوير، بدون نياز به اطلاعات اضافى يا ايجاد ييكسلهاى مخلوط

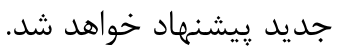
اين مقاله شامل ينج بخش است كه در بخش نخست

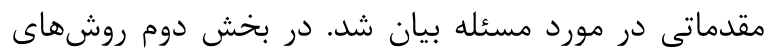

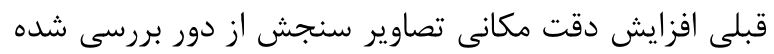
و يك مبحث جديد براى افزايش دقت مكانى ييكسلها در بخش سوم معرفى مىشود كه شيوه نوينى در اين زمينه بوده و هيج مشابهتى با روشهاى موجود ندارد و بهطور همزمان

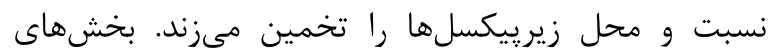
جهارم و هنجم بهترتيب شامل نتايج شبيهسازىها و جمعبندى است.

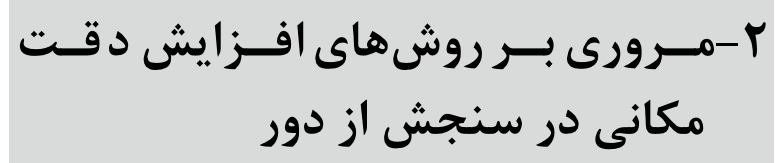

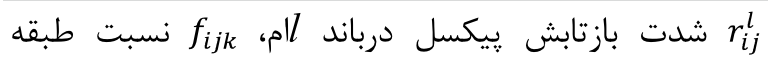
خالصk ام در ريكسل ، ${ }^{l}$ شدت بازتابش طبقه خالص

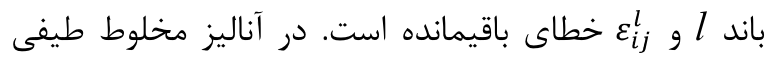


احتمال تعلق يك بردار شامل اطلاعات پِيكسل در باندهاى

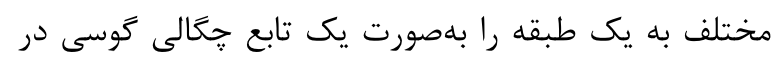

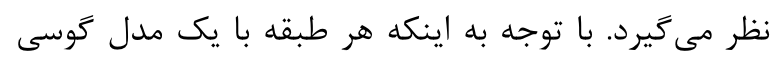

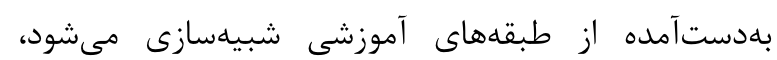

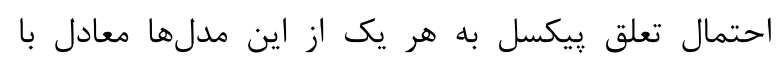

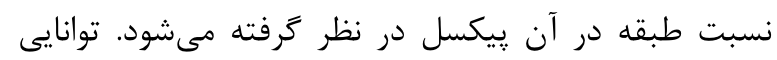

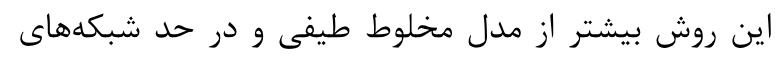

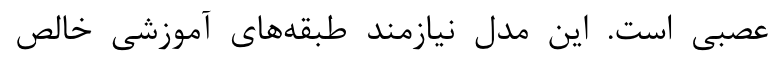

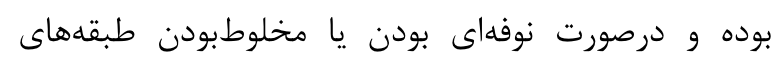
آموزشى با مشكل مواجه مىشود.

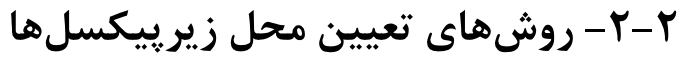
در اين قسمت روشهاى تعيين محل زيرييكسلها معرفى مىشوند كه بهطور معمول براساس بيشينهكردن تابع

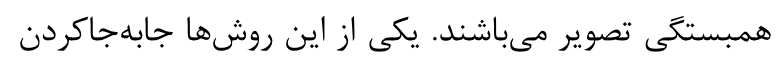

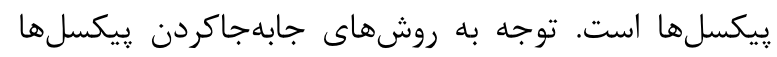

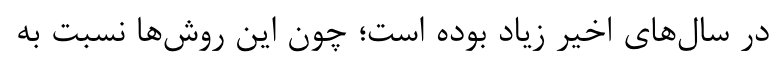

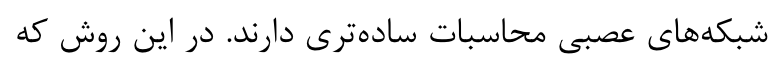

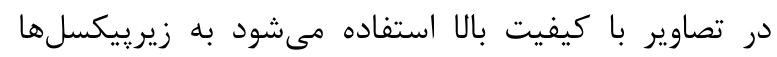

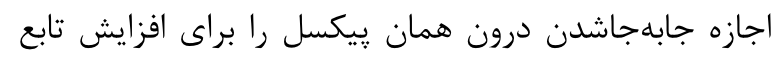

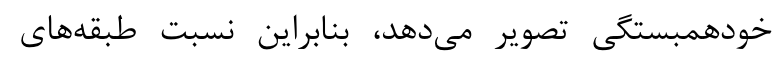

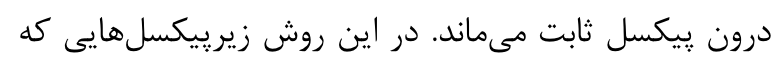

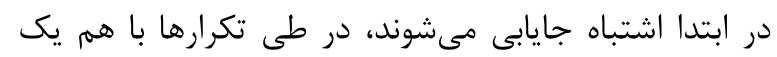

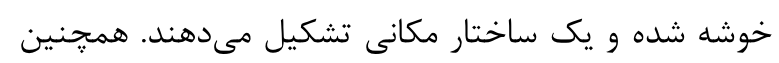

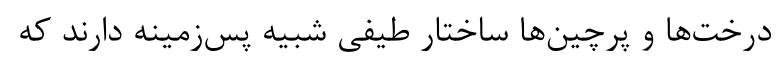
جداسازى آنها را مشكل مى كند [16]. اين روش برای براى

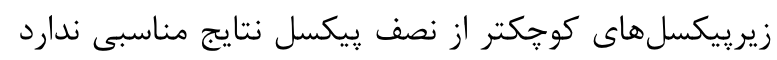
و بيشتر براى زيرييكسلهاى خطى مناسب است. [17] روشهاى مستقيم نكاشت ييكسلها بر بر اساس

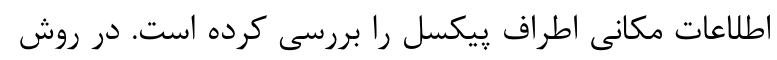

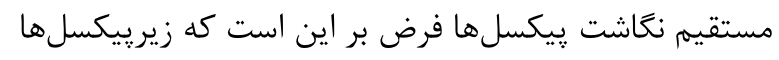

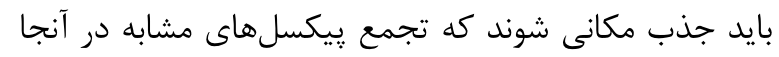

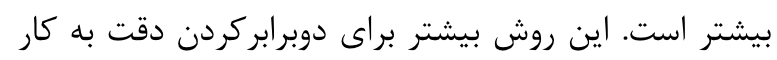

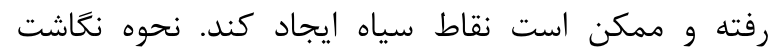
زيرييكسلهاى آموزشى اوليه صحت روش را بهشدت تحت

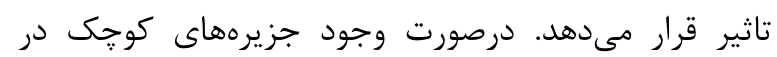

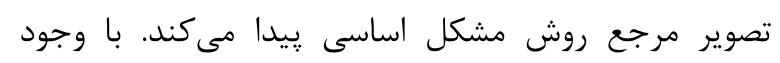

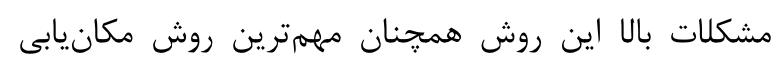

$$
\text { زيرييكسل هاس است [18]. }
$$

به غير از دو روش بالل، ساير روشهاى نماشت
زمينه استفاده از آن وجود دارد. از جمله، استفاده از معيار

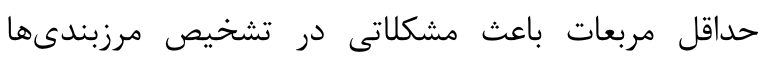

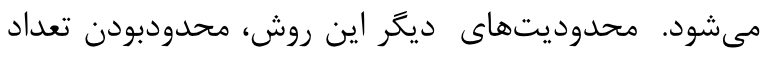

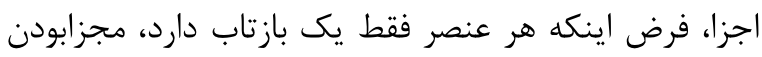
امضاى الكترومغناطيس طبقههاى خالص، حساسيت به نوفه و خطىبودن آن است. مدلهاى غيرخطى تجزيه طيفى نيز بررسى شدهاند[7]،[5] روش اصلى ديكر به كار رفته در طبقهبندى نرم

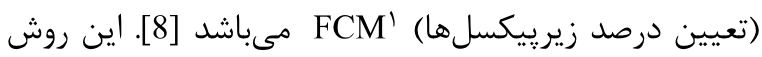

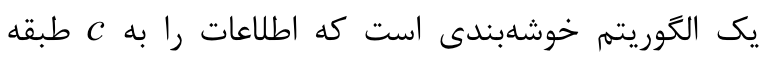

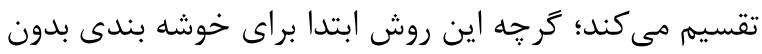

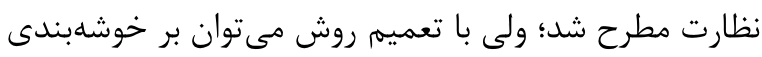

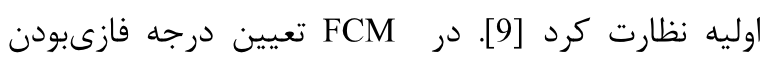

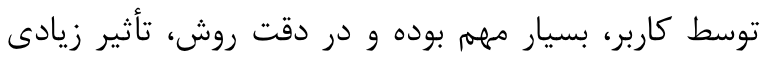

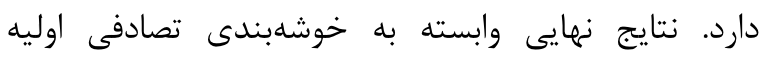

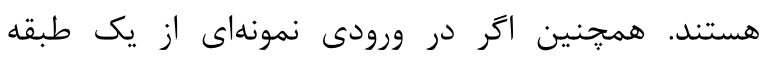

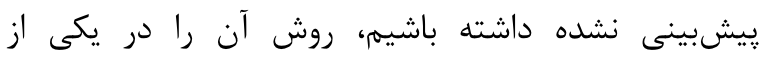
طبقههاى موجود طبقهبندى مى كند. براى حل اين مشكل

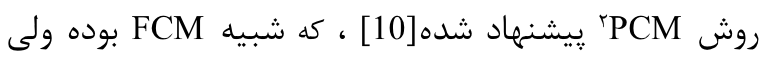

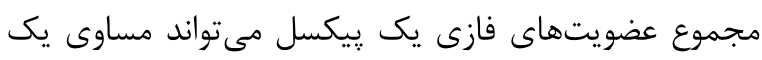
نباشد. بهبود اين روش در آن است كه عضويت بهدست آمده

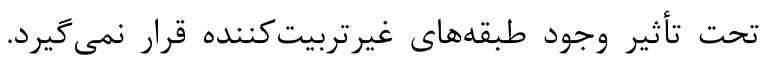
درصورت عدم وجود اين طبقهها صحت FCM بيشتر است. در سالهاى كذشته از شبكههاى عصبى ييشخور براى تشخيص زيرييكسلها استفاده شده است[12]،[11].

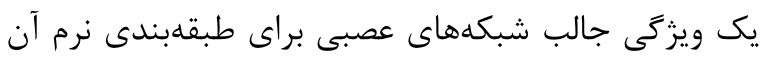

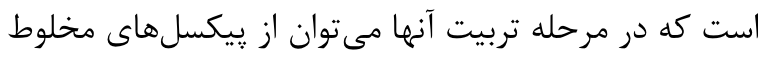

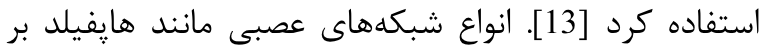

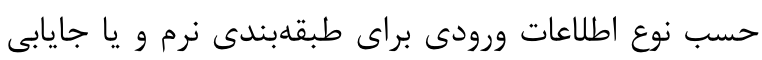

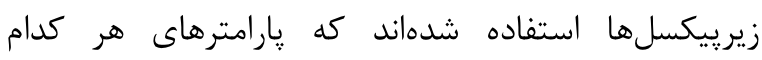
جداكانه تعريف مىشود. درنهايت هدف آنها بيشينهكردن

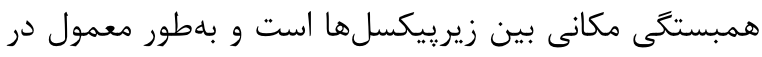

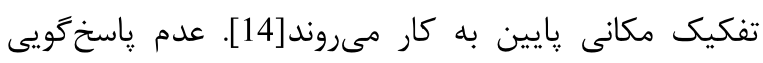

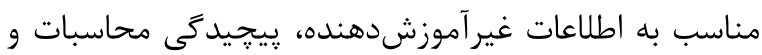
وقت كيربودن از مشكلات معمول آنها است.

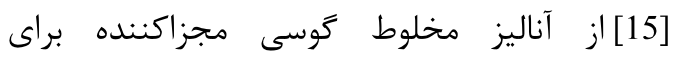
طبقهبندى زيرييكسلها استفاده كرده است. اين مجليز مدل

\footnotetext{
${ }^{1}$ fuzzy c-means (ميانكين فازى -c)

2 probability c-means (ميانكين محتمل -c)
} 
بودن اين كار، معيار خطا يا صحتى در كاربردهاى واقعى دئى

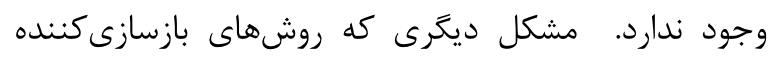

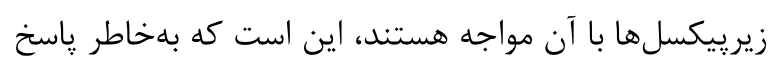
ضربه سنجندهها، تمام اطلاعات اكتسابى از آنها داراى ابهائ إبهام

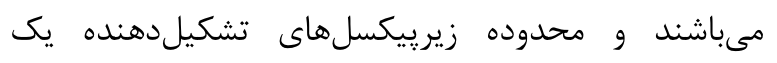

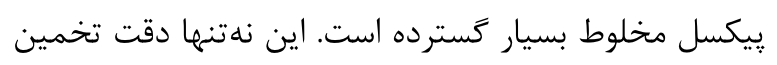

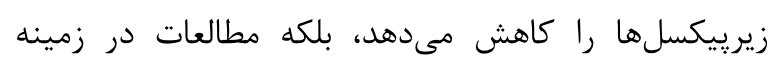

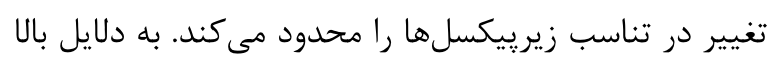

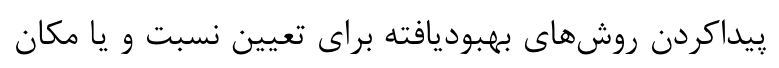

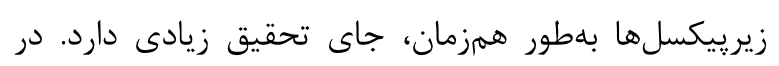

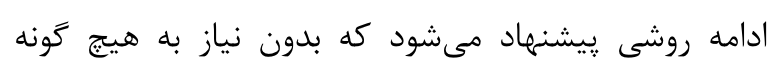

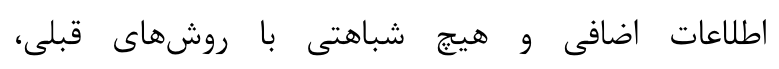

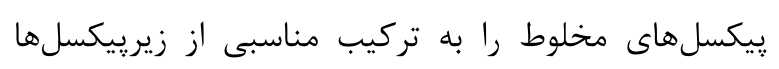

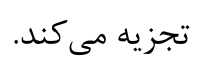

\section{r- روش جديد افزايش دقت مكانى تصاوير سنجش از دور با استفاده از جدول جستجو}

از آنجا كه اطلاعات تصاوير با كاهش تفكيك مكانى از بين

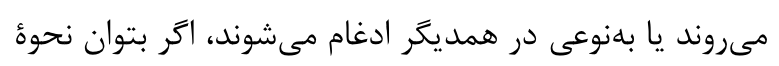

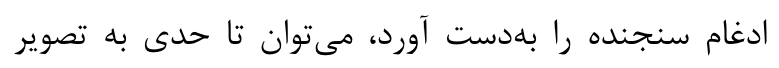

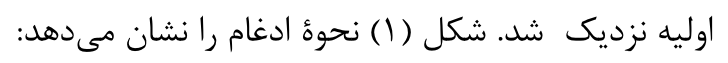

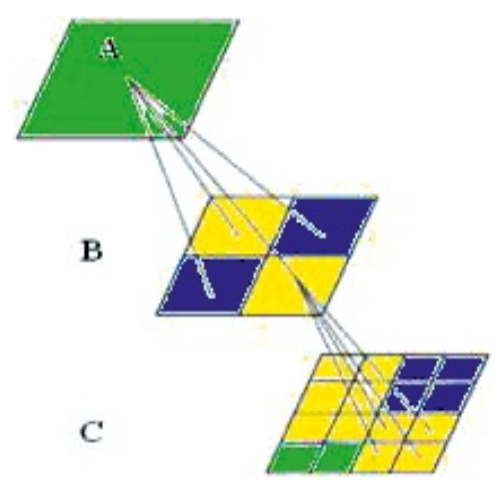

(شكل -(1): جِكَونَى ادغام بِيكسلها براى ايجاد تصاوير با دقت

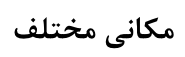

(Figure-1): The way of pixel merging to produce different resolution images

فرض كنيمrr شدت بازتابش يك پيكسل باشد. اين

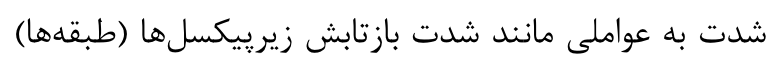

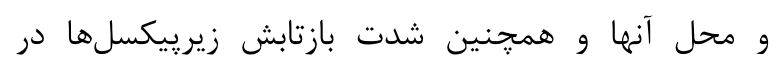
يكسل هاى مجاور بستخى دارد: $r=G\left\{c_{i}, p_{i}, q_{i}\right\}, i=1: K$
زيرييكسلها نيازمند اطلاعات ديخرى علاوهبر تصوير اصلى

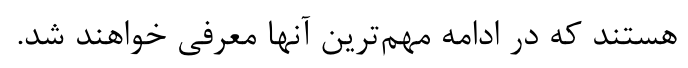

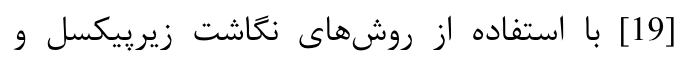
مدل هاى تصادفى ماركف سعى در كاهش مقياس كرده است.

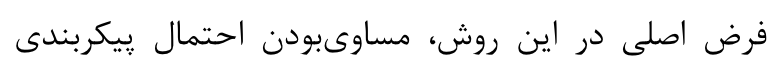

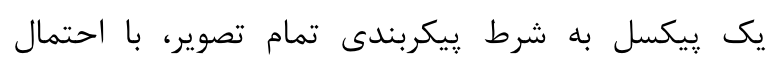

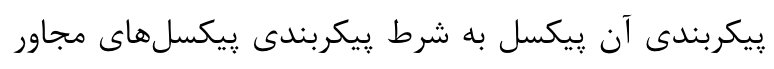

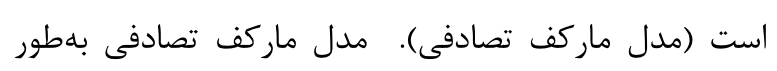

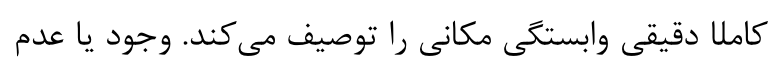

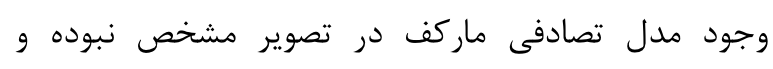

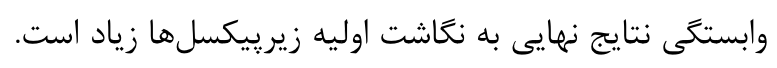
براى آموزش مناسب تعداد نمونههاى زيادى مورد نياز است.

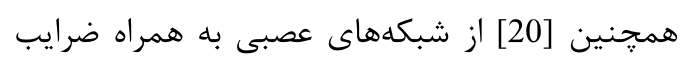

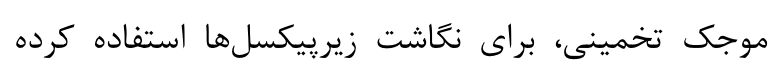

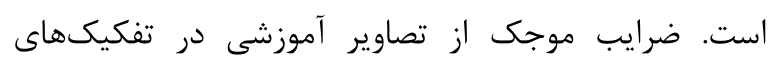

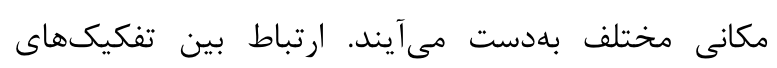

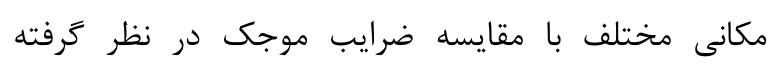

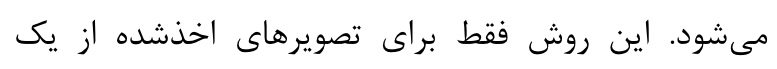
سنجنده كاربرد دارد.

[22]،[21] از روشهارديى بر اساس الكوريتم توليد مثل

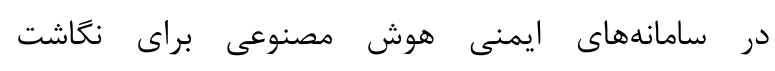

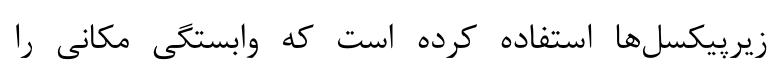

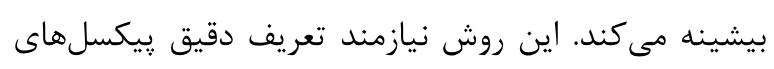

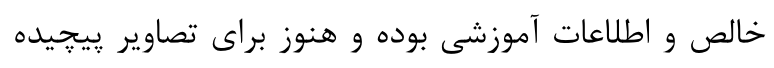
به كار نرفته است.

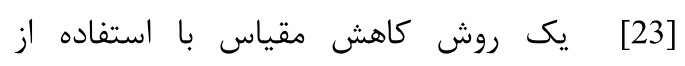

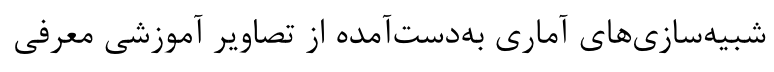

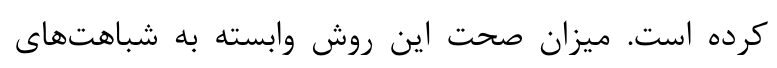
تصاوير ورودى و آموزشدهنده است است إن اين روش در اين بخش روشهايى براى تعيين نسبت و يا مكان

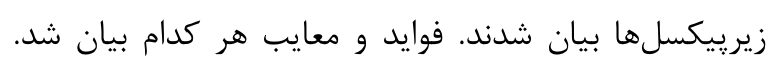

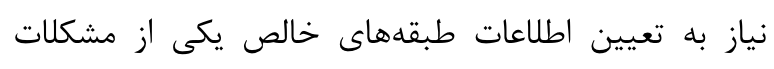

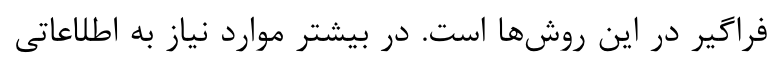

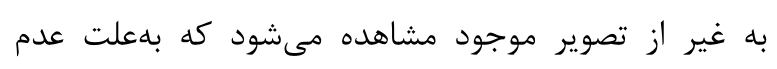

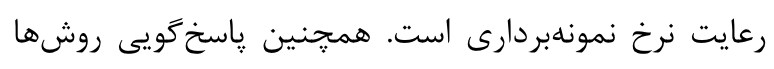

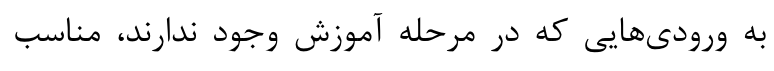

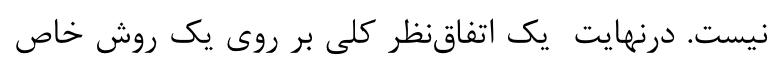

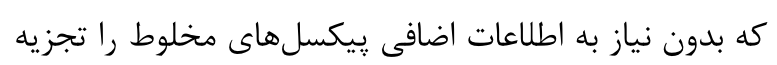

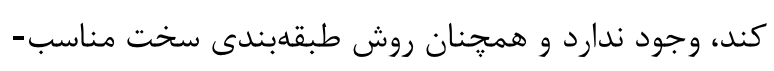

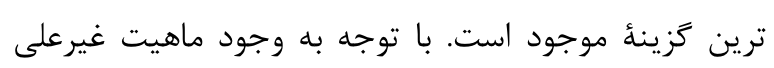


بنابراين اكر حداقل دو باند مستقل وجود داشته باشد، با

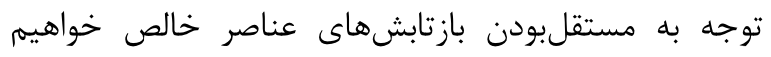

داشت:

$\left(f_{i j}^{\mathrm{Be}} \cong f_{m n}^{\mathrm{Ae}}\right),\left(f_{i j}^{\mathrm{Be}} \cong f_{m n 2}^{\mathrm{Ae}}\right)$

بنابراين درصورت مساوىبودن دامنه دو يیكسل در نواحى متناظر از A, B نسبت طبقههاى تشكيلدهنده آنها نيز مساوى خواهد بود.

از آنجا كه سنجندهها نسبت به بهابه

زيرييكسلها حساس نيستند، گزينههايى با ساختارهاى مختلف مكانى از زيرييكسلها خواهيم داشت كه در رابطه

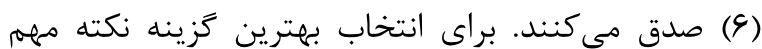

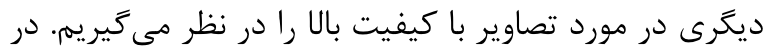

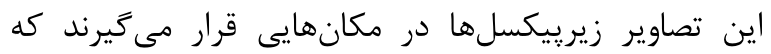
حداكثر تجمع از طبقههاى مشابه وجود دارد. بهعبارت ديخر

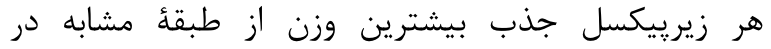
ييكسل هاى همسايه خواهد شد. بنابراين مكان هر زيريكان إيكسل تابعى از ساختار مكانى زيكسل هاى همسايه است. با توجه به نهانه

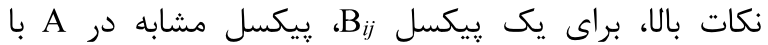

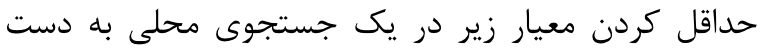

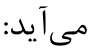
$\underset{\mathrm{r}_{3}, \mathrm{r}_{4}}{\arg }\left\{\min \sum_{r_{1}=-2}^{2} \sum_{r_{2}=-2}^{2} \sum_{l=1}^{L}\left|\mathrm{~B}_{\left(i+r_{1}\right)\left(j+r_{2}\right)}^{l}-\mathrm{A}_{\left(\left|\frac{i}{s}\right|+r_{1}+r_{3}\right)}^{l}\left(\left|\frac{\dot{j}}{s}\right|+r_{2}+r_{4}\right)\right|\right\}$ $, r_{3}, r_{4}=-r: r$

كه [إ نشاندهنده جزء صحيح i/s بوده كه براى درنظرگرفتن طبقههاى مشابه در دو تصوير استفاده شده و شعاع ناحيه جستجو است كه براى اجتناب از طبقههاى غير

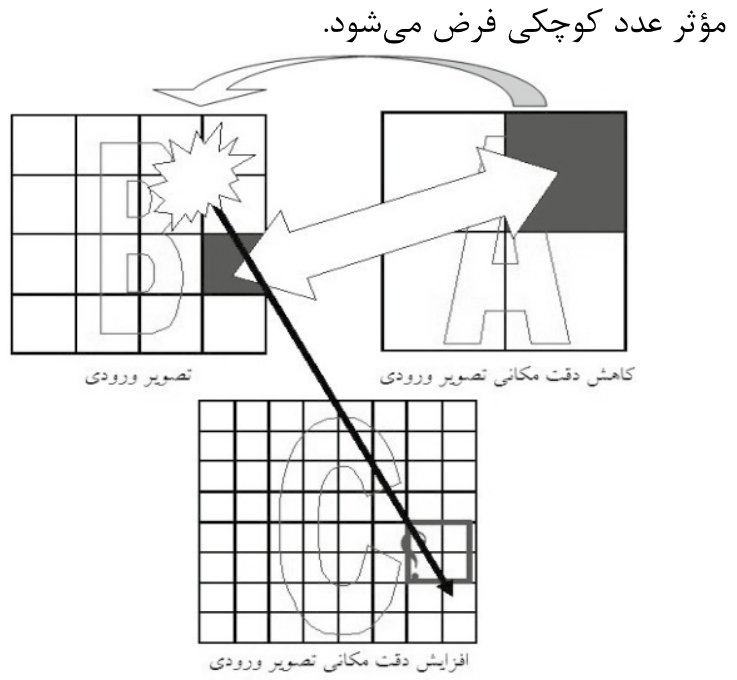

(شكل-r) : نمايش كرافيكى فر آيند جستجو در الكَوريتم

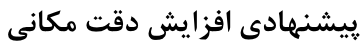

(Figure- 2): The graphical display of proposed search algorithm
كه ييكسلهاى مجاور مىباشد كه G لزوماً يك تابع خطى نيست. مشخص است كه بهدستآوردن دقيق مجهولات بالا كار مشكل و حتى غيرممكنى است و تنها با آزمايشهاى مختلف روى سنجنده مىتوان مجهولها را تعيين كرد. با

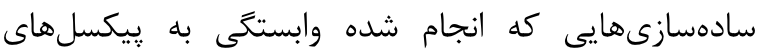
مجاور و همجنين فرض غيرخطىبودن حذف شده و شدت بازتابش بهصورت يك تركيب خطى از بازتابش طبقهها در نظر كرفته شده است (رابطه (1). جֶنانجه در بحث تجزيه مخلوط طيفى بيان شد، با حل معادلههاى بالا نسبت طبقهها بهدست مى آيد.

در روش جديد، براى حل دستخاه معادلات، ابتدا يك فضا از ززينههاى مناسب براى جواب ايجاد مى كنيم و در در بين آنها به دنبال بهترين زَينه ممكن مى مَرديم. در

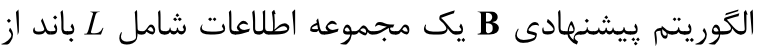
تصاوير M×N موجود با ميانكين گيرى يكنواخت از بلوكهاى افزايش دقت مكانى يافته تصاوير موجود است. هدف يافتن بلوكهايى براى تصوير C است كه يس از كاهش دقت

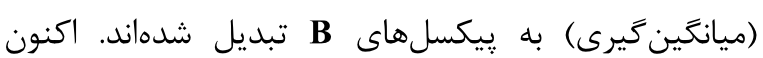
تجزيه طيفى ييكسل هاى B را در نظر مى خيريه: $r_{i j}^{\mathrm{B} l}=\sum_{k=1}^{K} f_{i j k}^{\mathrm{B}} c_{k}^{l}+\varepsilon_{i j}^{\mathrm{B} l}, \quad \sum_{k=1}^{K} f_{i j k}^{\mathrm{B}}=1$

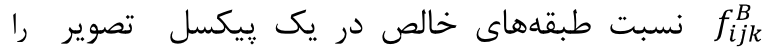

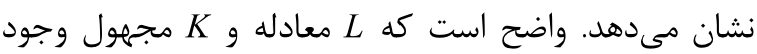
دارد. از آنجا كه بهطور معمول تعداد باندهاى مستقل و بدون نوفه از تعداد طبقهها كمتر بوده و شدت بازتابش عناصر خالص، ( رابطه (r) وجود ندارد. نكته ظريف آن است كه در تصاوير با نابـ، كيفيت بالا دامنه يك ييكسل بهطور معمول تابعى از شدت بازتابش دو يا حداكثر سه طبقهُ مجاور

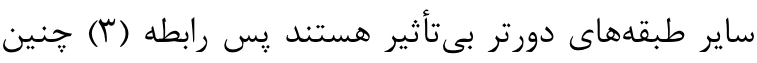

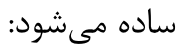

$r_{i j}^{\mathrm{B} l}=\sum_{k=1}^{3} f_{i j k}^{\mathrm{Be}} c_{k}^{\mathrm{e} l}+\varepsilon_{i j}^{\mathrm{Be}}, \quad \sum_{k=1}^{3} f_{i j k}^{\mathrm{Be}}=1$

شدت بازتابش يك ييكسل A در ناحيه متناظر با ييكسل بالا كه شامل طبقههاى مشابه مىباشد، جنين است: $r_{m n}^{\mathrm{Al}}=\sum_{k=1}^{3} f_{m n k}^{\mathrm{Ae}} c_{k}^{\mathrm{el}}+\varepsilon_{m n}^{\mathrm{Ae} l}, \quad \sum_{k=1}^{3} f_{m n k}^{\mathrm{Ae}}=1$

اتر دامنه دو ييكسل در نواحى متناظر A, B كه شامل طبقهاى مشابه هستند، مساوى باشد: $r_{i j}^{\mathrm{B} l} \cong r_{m n}^{\mathrm{A} l} \leftrightarrow\left(f_{i j 1}^{\mathrm{Be}}-f_{m n}^{\mathrm{Ae}}\right)\left(c_{1}^{\mathrm{e} l}-c_{3}^{\mathrm{e} l}\right)-$

$\left(f_{i j}^{\mathrm{Be}}-f_{m n 2}^{\mathrm{Ae}}\right)\left(c_{2}^{\mathrm{e} l}-c_{3}^{\mathrm{e} l}\right) \cong 0$ 
ورودى در يك دقت مكانى خاص بهره مىبرند و بهنام

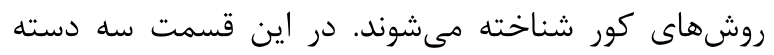

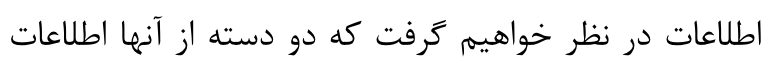

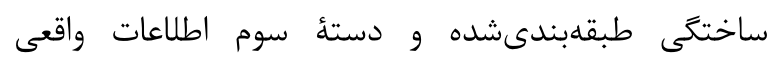

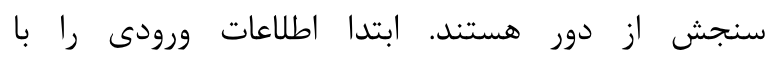
ميانگين كيرى يكنواخت روى بلوك هاى

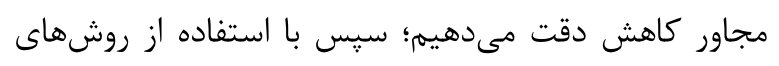

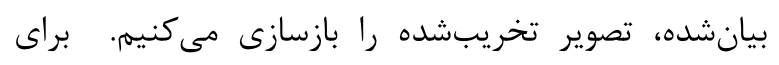

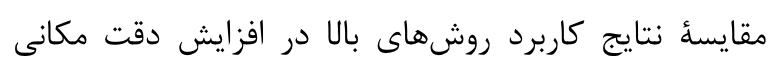

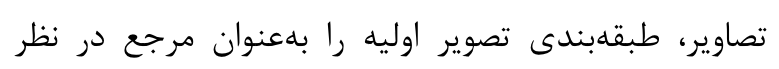

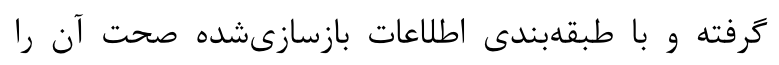

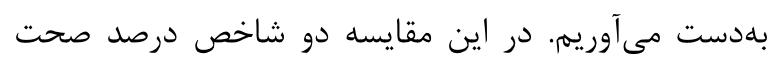
طبقهبندى (

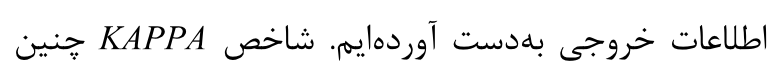

$$
\text { تعريف مىشود: }
$$

$K A P P A=\left[\sum_{i=1}^{K} w_{i}-\sum_{i=1}^{K} v_{i} u_{i}\right] /\left[1-\sum_{i=1}^{K} v_{i} u_{i}\right]$ (q)

كه درصد واقعى اين طبقه و w w حداقل اين دو است.

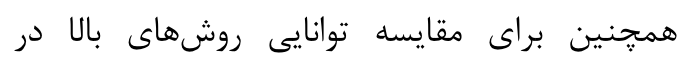

ازازسازى بيكسل هاى مخلوط شاخصهاى

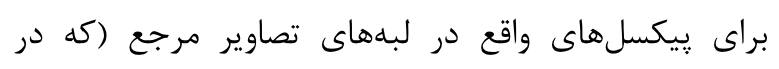

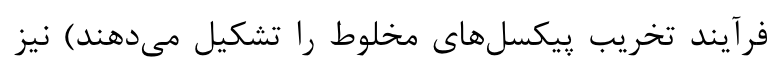

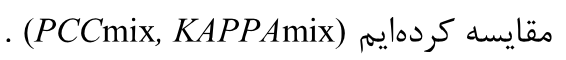

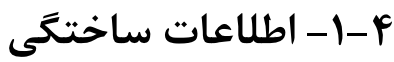

از آنجا كه درعمل بهطور معمول اطلاعات مكانى دقيقترى از إزلئ

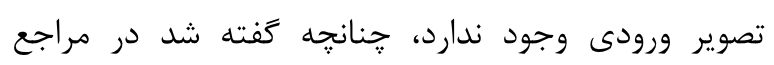

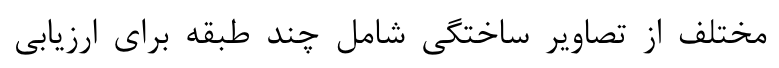
روشهاى افزايش دقت استفاده شده است.

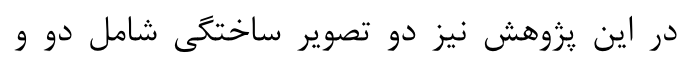

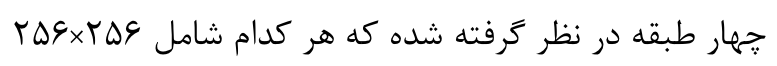

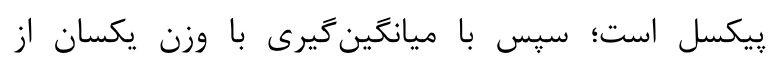

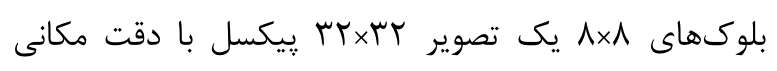

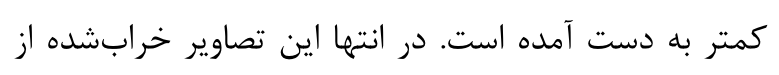

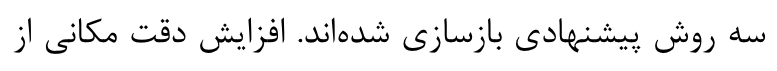

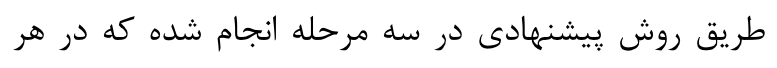

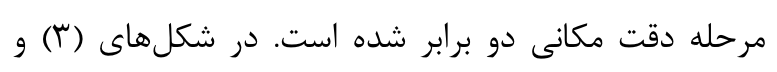

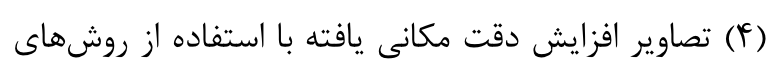

\footnotetext{
${ }^{1}$ Percent of Correction Classification
}

شكل (T) فرآيند جستجو را بهطور ساده نمايش مى دهد.

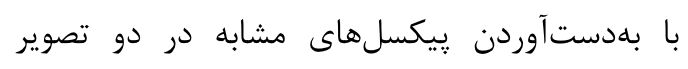

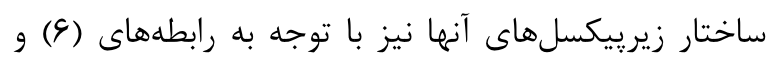

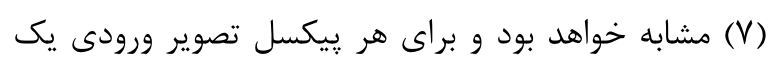

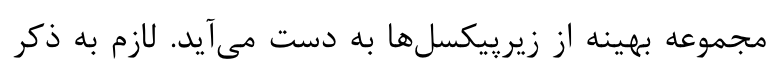

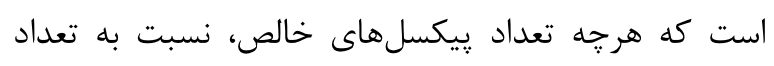

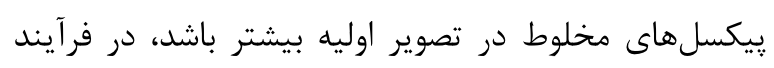

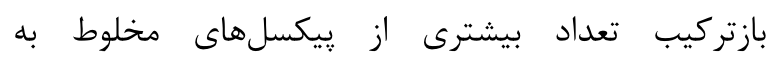

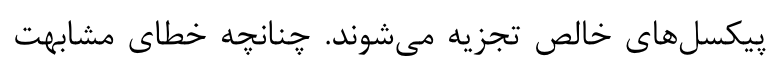

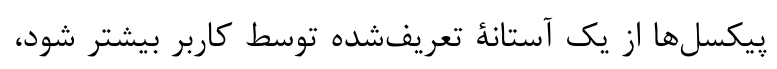
در اينصورت روش ييشنهادى قادر به تجزئه آن بيكسل

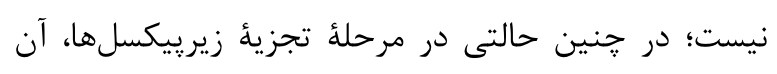

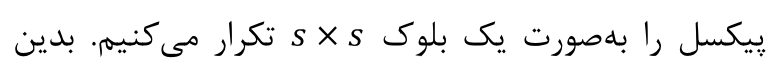
ترتيب مىتـوان اطمينان حاصل كرد كه خطاى طبقد

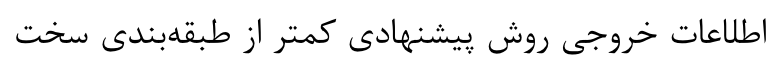

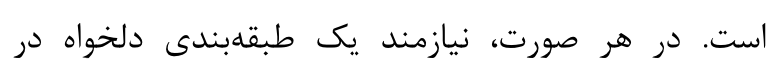
تصوير نهايى براى تعيين طبقه زيرييكسل ها هستيه.

\section{F}

مشخص است كه با هدف كاهش بيكسلهاى مخلوط، كليه

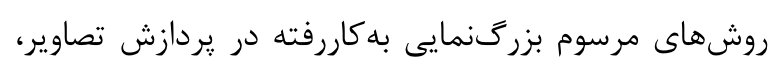

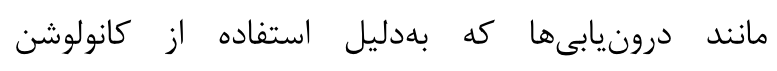

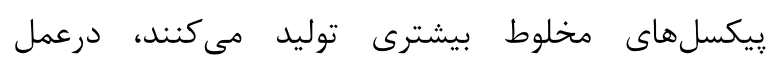
كاربردى در سنجش از دور ندارند [24]؛ همجنينين بهدليل

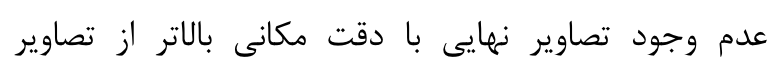

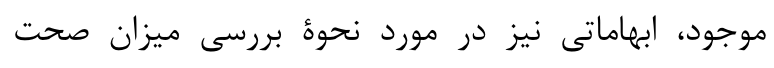

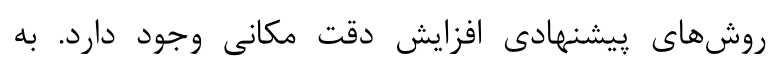

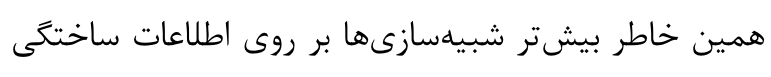

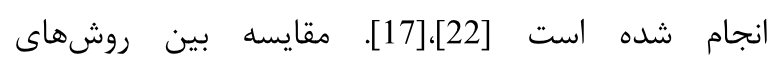

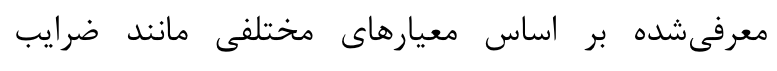

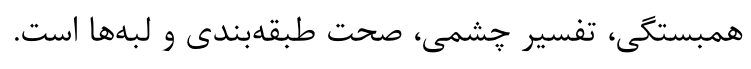

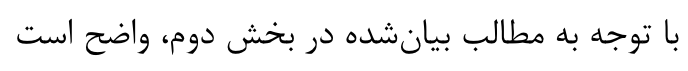
كه در بين روشهاى موجود افزايش دقت مكانى، تنها بـانها

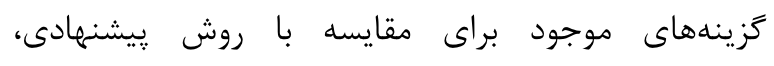

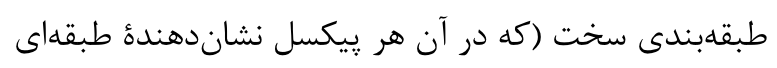

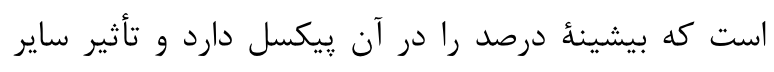

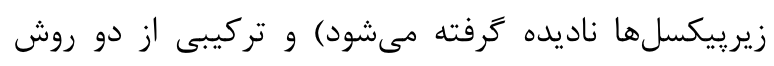
FCM نسبت و مكان زيرييكسلها نيازى به اطللاعات اضافى و

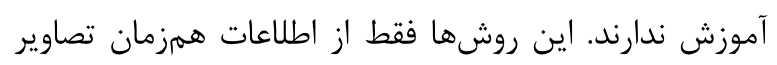


data. c, d: restoration of destroyed data using FCM+DIRECT and proposed methods respectively)

(جدول -1): مقايسه نتايج طبقهبندى روش هاى مختلف افزايش دقت مكانى براى اطلاعات ساختگى شامل دو طبقه

(Table-1): Comparison of different magnification methods for two classes of synthetic data

\begin{tabular}{|c|c|c|c|}
\hline & طبقهبندى سخت & $\begin{array}{c}\text { FCM+ } \\
\text { DIRECT }\end{array}$ & ريشنه روشادى \\
\hline$P C C$ & 0.98 & 0.98 & 0.99 \\
\hline$K A P P A$ & 0.96 & 0.96 & 0.98 \\
\hline$P C C \operatorname{mix}$ & 0.77 & 0.76 & 0.90 \\
\hline$K A P P A \operatorname{mix}$ & 0.62 & 0.61 & 0.90 \\
\hline
\end{tabular}

(جدول - Y): مقايسه نتايج طبقهبندى روشهاى مختلف افزايش

دقت مكانى براى اطلاعات ساختخَى شامل جههار طبقه

(Table-2): Comparison of different magnification methods for four classes of synthetic data

\begin{tabular}{|c|c|c|c|}
\hline & طبقهبندى سخت & $\begin{array}{c}\text { FCM+ } \\
\text { DIRECT }\end{array}$ & يِشنهادى روش \\
\hline$P C C$ & 0.95 & 0.92 & 0.97 \\
\hline$K A P P A$ & 0.93 & 0.88 & 0.95 \\
\hline$P C C$ mix & 0.77 & 0.67 & 0.85 \\
\hline$K A P P A \operatorname{mix}$ & 0.71 & 0.58 & 0.80 \\
\hline
\end{tabular}

(جدول -r): جدول ارزيابى خطاى طبقهبندى سخت در تخمين ييكسل هاى مخلوط (جههار طبقه)

(Table-3): Evaluation table of hard classification error for mixed pixels estimation (four classes)

\begin{tabular}{|c|c|c|c|c|c|}
\hline & C1 & C2 & C3 & C4 & تح \\
\hline C1 & 2700 & 319 & 515 & 0 & $76 \%$ \\
\hline C2 & 372 & 2218 & 181 & 0 & $80 \%$ \\
\hline C3 & 576 & 279 & 3726 & 218 & $77 \%$ \\
\hline C4 & 0 & 0 & 250 & 870 & $77 \%$ \\
\hline , اعتبار & $74 \%$ & $78 \%$ & $79 \%$ & $79 \%$ & \\
\hline
\end{tabular}

(جدول -F): جدول ارزيابى خطاى روش بيشنهادى در تخمين

ييكسل هاى مخلوط (جههار طبقه)

(Table-4): Evaluation table of proposed method error for mixed pixels estimation (four classes)

\begin{tabular}{|c|c|c|c|c|c|}
\hline & C1 & C2 & C3 & C4 & صح \\
\hline C1 & 3216 & 90 & 228 & 0 & $90 \%$ \\
\hline C2 & 166 & 2505 & 100 & 0 & $90 \%$ \\
\hline C3 & 532 & 225 & 3865 & 177 & $80 \%$ \\
\hline C4 & 0 & 0 & 333 & 787 & $70 \%$ \\
\hline , اعتبار & $82 \%$ & $88 \%$ & $85 \%$ & $81 \%$ & \\
\hline
\end{tabular}

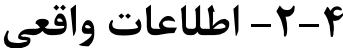

در اين قسمت دو دسته از اطلاعات سنجش از دور حومهٔ

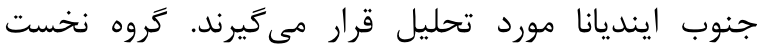

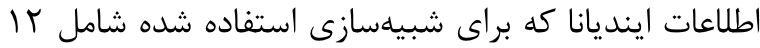

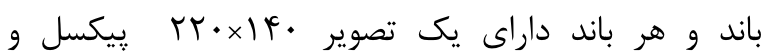
همجنين اطلاعات زمين مرجع است (شكل ه). اين اطلاعات

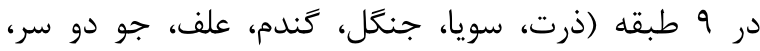

در جداول (1) و (Y) مقايسهاى بين نتايج صحت

طبقهبندى اطلاعات بازسازىشده توسط روشهاى مختلف افزايش دقت مكانى ديده مىشود كه نشاندهندهُ بهبود نسبى شاخصهاى طبقهبندى توسط روش معرفى شده است. همجنين براى بررسى بهتر، جداول (r) و (f) ارزيابى دقيقى از جگَونَى خطاى ايجادشده در بازسازى ييكسل هاى مخلوط در طبقهبندى سخت و روش ييشنهادى را نشان
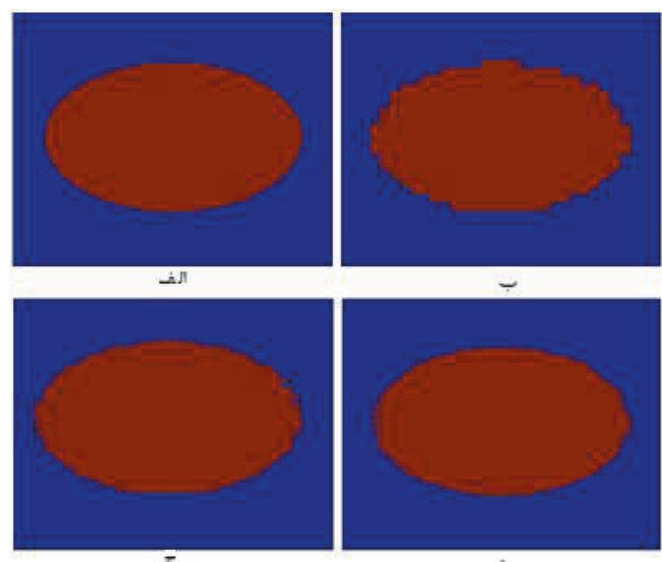

(شكل - (ץ): مقايسه خروجى هاى روشهاى مختلف افزايش دقت مكانى (الف: اطلاعات مرجع. ب: طبقهبندى سخت اطلاعات خراب

شده. ج، د: بازسازى اطلاعات خرابشده توسط روشهاى

FCM+DIRECT

(Figure -3): Comparison of different magnification methods utputs (a: reference data. b: hard classification of destroyed da ${ }^{\text {ta. }}$ c, d: restoration of destroyed data using FCM+DIRECT and proposed methods respectively)

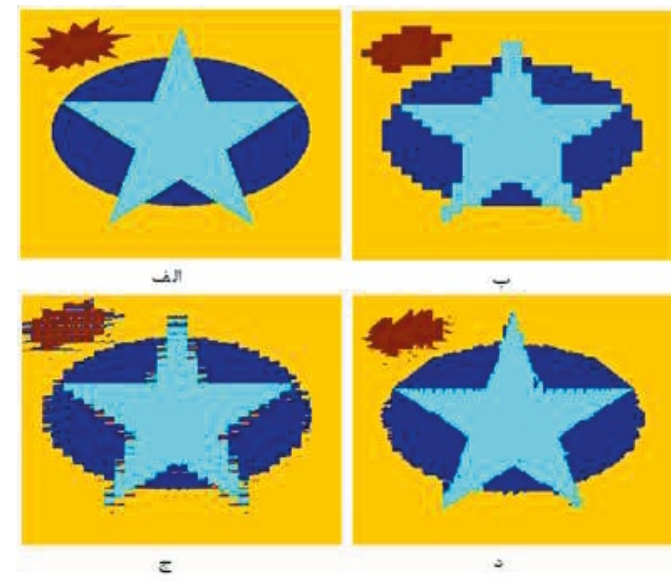

(شكل - +1): مقايسه خروجى هاى روشهاى مختلف افزايش دقت مكانى (الف: اطلاعات مرجع. ب: طبقهبندى سخت اطللاعات خراب

شده. ج، د: بازسازى اطلاعات خرابشده توسط روشهاى

FCM+DIRECT

(Figure-4): Comparison of different magnification methods outputs (a: reference data. b: hard classification of destroyed 
• • r باند انتخاب شده و با استفاده از • له نمونه آموزشى در يازده طبقه طبقهبندى شدهاند. اين اطلاعات با ميانگين گيرى

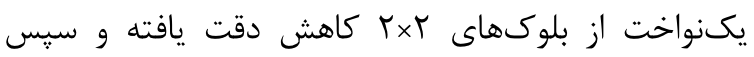

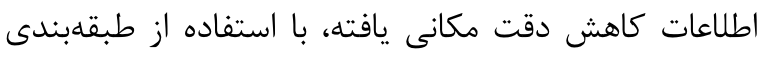
سخت و روش پيشنهادى، افزايش دقت مكانى پيدا كردهاند. شكل (و) اطلاعات بالا و جدول (و) مقايسهاى بين بين نتايج طبقهبندى را نشان مىدهد.

(جدول -ه): مقايسه نتايج طبقدبندى سخت و روش بيشنهادى

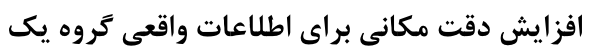

(Table-5): Comparison of group one classification results using hard classification and proposed method

\begin{tabular}{|c|c|c|c|}
\hline & اطلاعات مرجع & طبقهبندى سخت & روش بيشنهادى \\
\hline$P C C$ & 0.73 & 0.77 & 0.79 \\
\hline$K A P P A$ & 0.66 & 0.71 & 0.73 \\
\hline$P C C \operatorname{mix}$ & 0.56 & 0.35 & 0.63 \\
\hline KAPPAmix & 0.58 & 0.28 & 0.55 \\
\hline
\end{tabular}

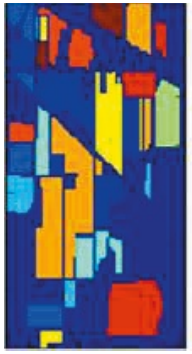

$\checkmark$

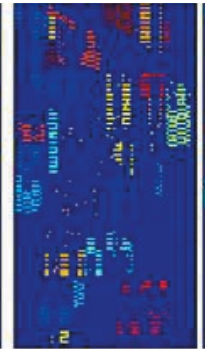

ج

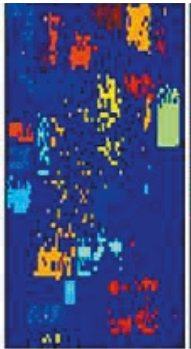

ب

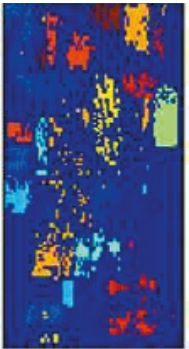

الف
(شكل - ( ): مقايسه طبقلبندىهاى مختلف اطلاعات واقعى دسته دو با زمين مرجع. (الف: زمين مرجع. ب: طبقهبندى اطلاعات

مرجع. ج: طبقهبندى سخت. د: روش بيشثنهادى)

(Figure-6): Comparison of different classification of group two with ground reference (a: ground reference data. b: reference classification. c: hard classification of destroyed data. d: restored data using proposed method.)

(جدول -9): مقايسه صحت طبقهبندى اطلاعات واقعى گروه دو در مقايسه با زمين مرجع

(Table-5): Comparison of group two classification results using hard classification and proposed method

\begin{tabular}{|c|c|c|c|}
\hline & طبقد & & \\
\hline$P C C$ & 0.65 & 0.71 & 0.72 \\
\hline KAPPA & 0.50 & 0.60 & 0.61 \\
\hline PCCmix & 0.62 & 0.51 & 0.54 \\
\hline KAPPAmix & 0.48 & 0.36 & 0.40 \\
\hline
\end{tabular}

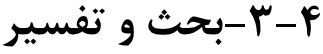

در بررسى شبيهسازىهاى بالا نكات قابل توجهى وجود دارد.

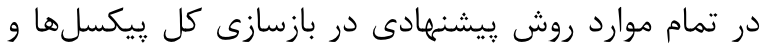

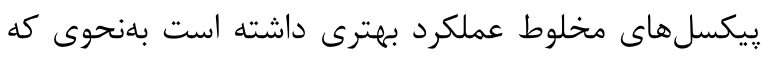

مرتع، يونجه و جاده) طبقهبندى شدند؛ سيس اين اطلاعات با

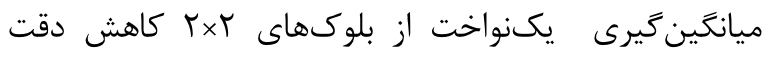

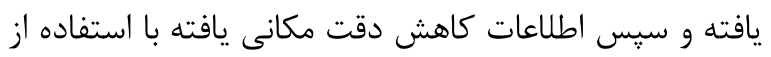

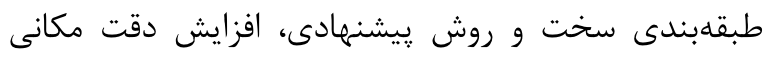

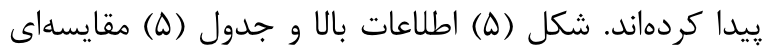
بين نتايج طبقهبندى را نشان مى دهد '.

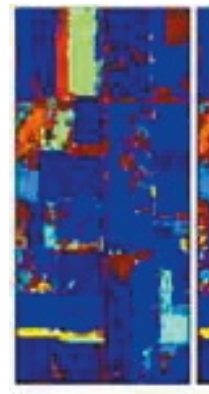

3

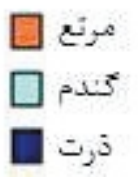

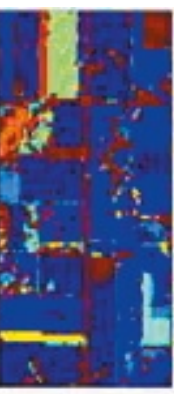

$\varepsilon$

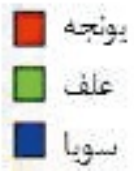

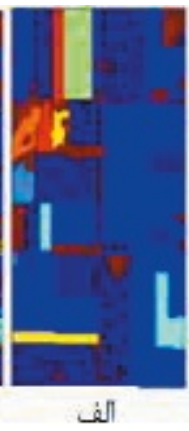

Dobl

$\square, \cos$

$\square$ Lis
(شكل -ه): اطلاعات بخش جنوبى تايتكانو، اينديانا. شامل rا باند +F|F با استفاده از سنجنده M7. (الف: اطلاعات زمين مرجع. ب: طبقهبندى اطلاعات ورودى. ج: طبقهبندى سخت اطللاعات خرابشده. د: بازسازى اطلاعات خرابشده توسط روش إى ييشنهادى)

(Figure-5): Data of south taipkano, Indiana. Consist of 12 bands, each band contain $220 * 140$ pixels of nine classes (a: ground reference data. b: reference classification. c: hard classification of destroyed data. d: restored data using proposed method.)

كروه دوم اطلاعات اينديانا در · ·r باند و هر باند شامل يك

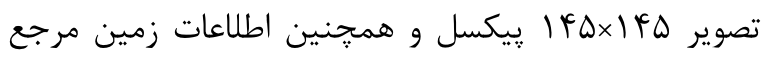

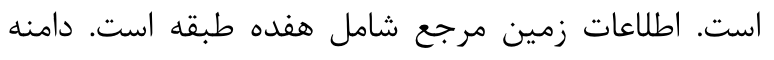

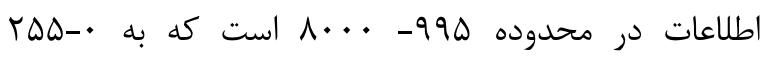

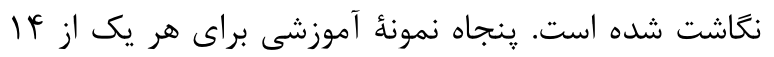

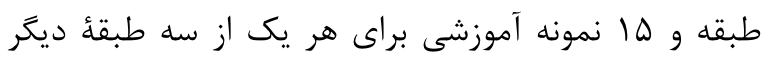

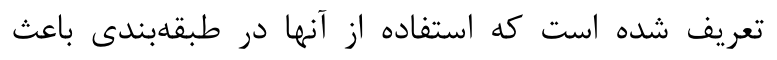

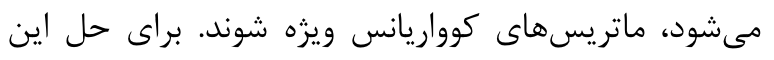

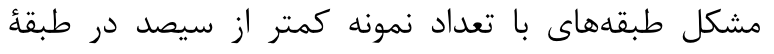

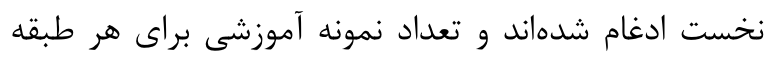

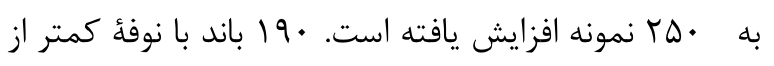

${ }^{1}$ https://engineering.purdue.edu/ biehl/MultiSpec/ hyperspectral.html 
ييشنهادى است. گرحه اين روش براى تصاوير با كيفيت بالا ييشنهاد شده، ولى كاربردهاى مختلفى در تصاوير مختلف

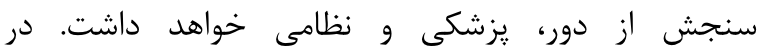
يثوهشهاى بعدى، سعى در تعميم روش بالا به تصاوير با كيفيت يايين خواهد شد.

\section{6-Refrences}

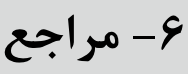

[1] J.J. Settle, N.A. Drake, "Linear Mixing and the Estimation of Ground Cover Proportions", International Journal of Remote Sensing, Vol. 14, No. 6, pp.1159-1177, 1993.

[2] J. Li, Q. Yuan, H. Shen, X. Meng and L. Zhang, "Hyperspectral Image Super-Resolution by Spectral Mixture Analysis and Spatial-Spectral Group Sparsity", IEEE Geoscience and Remote Sensing Letters, Vol. 13, No. 9, pp. $1250-$ 1254, 2016.

[3] C. Wu, A.T. Murray, "Estimating Impervious Surface Distribution by Spectral Mixture Analysis", Remote Sensing Of Environment, Vol. 84, pp. 493-505, 2003.

[4] Zhang Hongen, Lin Qizhong, Liu Suhong, Shi Jiancheng, "Sub-Pixel Lake Mapping In Tibetan Plateau", Geoscience And Remote Sensing Symposium, Proceedings IEEE, Vol. 5, pp .3073 - 3076, 2004

[5] L. Weiguo Elaine, Y. Wu, "Comparison Of NonLinear Mixture Models: Sub-Pixel Classification", Remote Sensing Of Environment, Vol. 94, pp.145-154, 2005.

[6] G.M. Foody, R.M. Lucas, P.J. Curran and M. Honzak, "Non-Linear Mixture Modeling Without Endmembers Using An Artificial Neural Network", International Journal of Remote Sensing, Vol. 18, pp. 937-953, 1997.

[7] Z. Mitrak, F. Del Frate, "Non-linear spectral mixture analysis of Landsat imagery by means of neural networks", IEEE International Geoscience and Remote Sensing Symposium (IGARSS), pp. 1765 - 1768, 2015.

[8] G.M. Foody, D.P. Cox, "Sub-Pixel Land Cover Composition Estimation Using A Linear Mixture Model And Fuzzy Membership Functions", International Journal Of Remote Sensing, Vol. 15, pp. 619-631, 1994.

[9] J. Zhang, G.M. Foody, "Fully-Fuzzy Supervised Classification Of Sub-Urban Land Cover From Remotely Sensed Imagery: Statistical And Artificial Neural Network Approaches", International Journal Of Remote Sensing, Vol. 22, No.4, pp. 615-628, 2001

[10] G.M. Foody, "Estimation Of Sub-Pixel Land Cover Composition In The Presence Of Untrained Classes", Computers \& Geosciences, Vol. 26, pp.469-478, 2000.
در اطلاعات ساختخى صحت طبقهبندى را حداقل 1 ٪ و در ييكسلهاى مخلوط حداقل V٪\% بهبود داده است. در اطلاعات

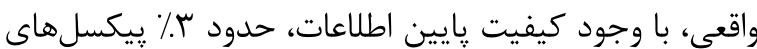
مخلوط بيشترى، صحيح طبقهبندى شدهاند. اعتبار و صحت بـ طبقهبندى نيز، بهجز در يك مورد، در ساير حدقل r/ بهبود

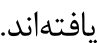

يك مقايسُٔ جشمى نيز نشاندهندهُ بهبود نسبى اطلاعات بازسازىشده توسط روش ييشنهادى، بهخصوص در

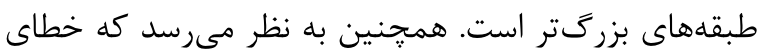
تعيين درصد زيرييكسلها در روش FCM+DIRECT زياد بوده و اطلاعات لبهها در طبقهبندى سخت از بين رفتهاند.

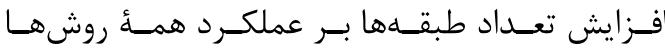

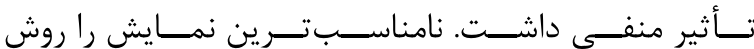
FCM+DIRECT داشـت و از آنجـا كـهـ تشـخيص طبقـهـها در تصـوير خروجسى آن غيـرممكن بـود، مجبـور بـه حسـذف آنس

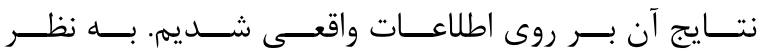

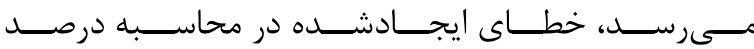
زيرييكسلهــا باعـث ايسن عملكـرد ضـعيف شـده اسـت كـهـ

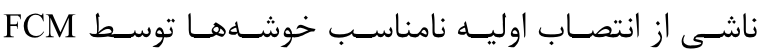

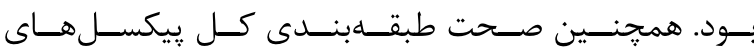

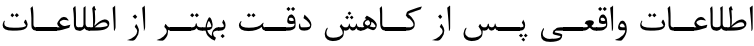

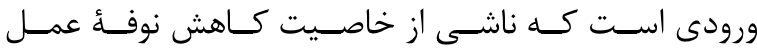

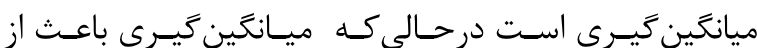
بين رفتن اطلاعات لبهها شده است. جنانجه در بررسى اطلاعات واقعى ديده مىشود، كاهش تعداد ييكسلهاى خالص نسبت به بيكسل ترهاى مخلوط تأثير منفى بر عملكرد روش پيشنهادى حذاشته

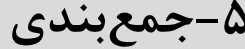

با توجه به بررسىهاى انجامشده به نظر مىرسد روش جديد

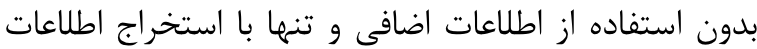
كمتر به جشم آمدهُ موجود در تصاوير، توانايى بهبود دقت

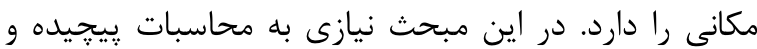
تصاوير خاص و آموزش ندارد. احتياجى به محاسبه جداگانه درصد و محل زيرييكسلها نيست. توانايى اين روش در لبههاى استخراجشده نيز واضح است و مىتوان كيفيت لبهها را بهعنوان معيارى در ميزان صحت نتايج در نظر گرفت. محاسبة شاخصهاى طبقهبندى نيز مؤيد توانايى روش 
Remote Sensing Symposium, Vol. 3, pp.10071010, 2009.

[22] X. Tong, X. Xu, A. Plaza, H. Xie, H. Pan, W. Cao and D. LvA, "New Genetic Method for Subpixel Mapping Using Hyperspectral Images", IEEE Journal of Selected Topics in Applied Earth Observations and Remote Sensing, Vol. 99, pp. 1-12, 2016.

[23] A. Boucher, "Sub-Pixel Mapping Of Coarse Satellite Remote Sensing Images With Stochastic Simulations From Training Images", Mathematical Geoscience, Vol. 41, pp.265-290, 2009.

[24] M. Zeinali, H. Ghassemian and M.N. Moghaddasi, "A New Magnification Method For Rgb Color Images Based On Subpixels Decomposition", IEEE Signal Processing Letters, Vol. 21, No. 5, pp. 577-560, 2014.

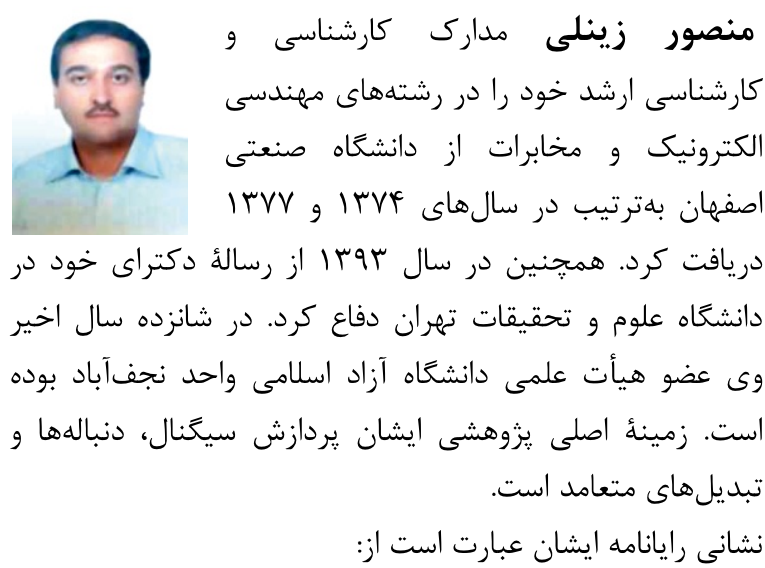

mansoorzeinali@pel.iaun.ac.ir

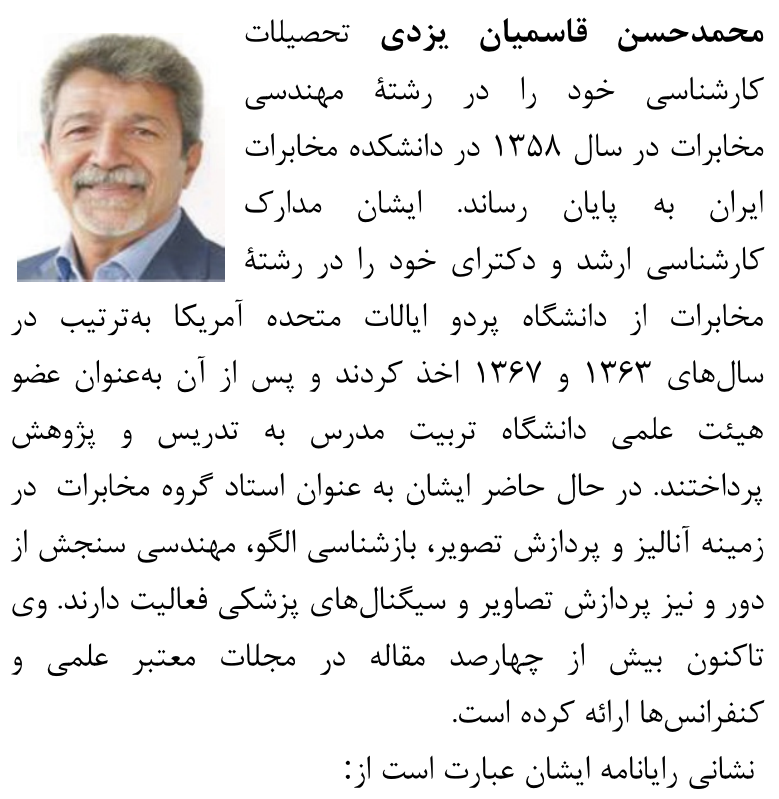

ghassemi@modares.ac.ir
[11] Q. Fang, "Neuro-Fuzzy Based Analysis Of Hyper Spectral Imagery", Photogrammetric Engineering \& Remote Sensing, Vol. 74, No. 10, pp. 1235-1247, 2008.

[12] P.M. Atkinson, A.R.L. Tatnall, "Introduction: Neural Networks In Remote Sensing", International Journal Of Remote Sensing, Vol. 18, pp. 699-709, 1997.

[13] G.M. Foody, M.K. Arora, "An Evaluation Of Some Factors Affecting The Accuracy Of Classification By An Artificial Neural Network", International Journal Of Remote Sensing, Vol. 18, pp. 799-810, 1997.

[14] M.Q. Nguyen, P.M. Atkinson and G.L. Hugh, "Superresolution Mapping Using A Hopfield Neural Network With Fused Images", IEEE Transactions On Geoscience And Remote Sensing, Vol. 44, No. 3, pp. 736-750, 2006.

[15] C.E. Woodcock, S. Gopal, and W. Albert, "Evaluation Of The Potential For Providing Secondary Labels In Vegetation Maps", Photogrammetric Engineering \& Remote Sensing, Vol. 62, pp. 393-399, 1996.

[16] M.W. Thornton, P.M. Atkinson and D. A. Holland, "Sub-Pixel Mapping Of Rural Land Cover Objects From Fine Spatial Resolution Satellite Sensor Imagery Using SuperResolution Pixel-Swapping", International Journal Of Remote Sensing, Vol. 27, No. 3, pp.473-491, 2006.

[17] C.M. Koen, B.D. Baets, L.P.C. Verbeke and R.R. De Wulf, "Direct Sub-Pixel Mapping Exploiting Spatial Dependence", Geoscience And Remote Sensing Symposium, IEEE, pp. 3046-3050, 2004.

[18] Qunming Wang, Wenzhong Shi and Liguo Wang, "Allocating Classes For Soft-Then-Hard Subpixel Mapping Algorithms In Units Of Class", IEEE Transactions On Geoscience And Remote Sensing, Vol. 52, No. 5, pp. 2940 2959, 2014.

[19] T. Kasetkasem, M.K. Arora, P.K. Varshneyp, "Super-Resolution Land Cover Mapping Using A Markov Random Field Based Approach Remote Sensing Of Environment", Remote Sensing Of Environment, Vol. 96, pp. 302-314, 2005.

[20] C.M Koen, L.P.C. Verbeke, , T. Westra and R.R. De Wulf., "Sub-Pixel Mapping And Sub-Pixel Sharpening Using Neural Network Predicted Wavelet Coefficients", Remote Sensing Of Environment, Vol. 91, pp.225-236, 2004.

[21] Y. Zhong, L. Zhang, P. Li, and H. Shen, "A SubPixel Mapping Algorithm Based On Artificial Immune Systems For Remote Sensing Imagery", IEEE International Geoscience And 